IN brief

\section{Mixed news for Avastin}

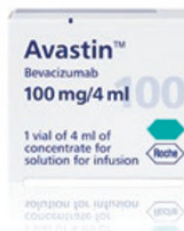

Avastin's trial failure

could have pushed down Genentech's stock.

It came as a shock, on April 21, when Roche of Basel announced that a highly anticipated phase 3 trial of Avastin in early-stage colon cancer had missed its primary endpoint.

$\Varangle$ The humanized monoclonal antibody (mAb; bevacizumab), developed by the S. San Francisco,

California-based Genentech, is a vascular endothelial growth factor (VEGF) blocker, and the company's best selling product. A successful trial for early-stage colon cancer would have boosted drug sales considerably, but results from the $\mathrm{C}-08$ trial evaluating Avastin in combination with chemotherapy after tumor resection in 2,700 patients showed that the mAb failed to reduce the risk of recurrence. This proved a major disappointment to the Swiss pharma, which had only a month earlier completed a $\$ 46.8$ billion takeover of Genentech. News of the trial failure sent Roche's shares tumbling and instigated talk that the Swiss company may have paid too much for the biotech. Had the results been known at the time of closing the deal Roche might have bought Genentech at a lower price. The good news came on May 5 when the US Food and Drug Administration approved Avastin as a therapy for recurrent glioblastoma multiforme in patients with refractory progressive disease. Avastin's approval for glioblastoma, an indication worth \$300-\$400 million per year, according to New York City-based senior biotech analyst George Farmer of Canaccord Adams in Vancouver, British Columbia, won't offset its loss in early-stage colorectal cancer for which analysts had estimated $\$ 1$ billion per year in additional revenue. That Avastin is not active as an adjuvant in early colorectal cancer is perplexing, considering the success the drug has enjoyed in treating late-stage metastatic colorectal cancer, as well as advanced lung and breast cancers. "We know very little about the role of VEGF in the early stages of cancer progression," says cancer biologist and translational investigator Rakesh Jain, director of the Edwin L. Steele Laboratory for Tumor Biology at Harvard Medical School in Boston. "VEGF is just the first line in making blood vessels in tumors, and there are other pathways and growth factors including inflammatory cytokines that are needed for making blood vessels and that contribute to tumor progression and metastasis." Despite the setback, Roche is committed to testing Avastin in other programs, and in early-stage cancer. "But the potential of Avastin in other adjuvant settings, including breast and lung cancers, is questionable as well," says Farmer. "Now in hindsight it looks like Roche overpaid, based on the outcome of that [C-08] study."

George S Mack

\section{Ariad's NFKB patent claims shot down on appeal}

On April 3, a federal appeals court ruled in favor of Eli Lilly in Indianapolis, Indiana, capping a seven-year legal fight with Ariad Pharmaceuticals over its patent claims surrounding nuclear factor kappa $\mathrm{B}(\mathrm{NF} \mathrm{B})$. The case has embroiled big pharma, several prominent biotech companies and even Nobel Prize winners as courtroom witnesses in a high-stakes tussle over the commercial reach of patents with especially broad claims. The recent verdict reverses a 2006 jury ruling in favor of the Cambridge, Massachusetts-based Ariad, a decision that had, back then, surprised and alarmed many in the biotech industry (Nat. Biotechnol. $24,737,2006)$. The dispute centered on Lilly's osteoporosis drug Evista (raloxifene) and sepsis drug Xigris (activated protein C), but the case's implications extended far beyond these two drugs. "Ariad sought to assert claims that are broad far beyond the scope of the [patent] disclosure," wrote appeals court Judge Kimberly Ann Moore in her opinion reversing the jury verdict.

The patent's claims were indeed broad. They encompassed all methods for lowering cellular levels of $\mathrm{NF} \kappa \mathrm{B}$, a transcription factor involved in inflammation. NFkB was discovered in 1986 by Nobel Prize winner David Baltimore, then at the Massachusetts Institute of Technology (MIT). MIT, Harvard University and the Whitehead Institute, all of Cambridge, Massachusetts, together shared the patent. Because NFкB is so important in biology and disease-it has been implicated in arthritis, cancer, diabetes and stroke-the claims essentially gave Ariad, who had gained an exclusive license for the patent from the Cambridge group in 1991, patent rights over scores of marketed and experimental drugs that acted, directly or indirectly, on the

Ariad used the license aggressively, suing Lilly for infringement the day the patent issued in 2002, and sending letters to about 50 other companies asking them to license the patent. Lilly fought back hard, as did Amgen in Thousand Oaks, California, which filed a preemptive suit against Ariad in 2006 to invalidate the patent and certify that its rheumatoid arthritis drug Enbrel (etanercept) does not infringe.

The Amgen case is still unresolved, but Lilly's victory appears decisive. Despite the earlier jury verdict in Ariad's favor, "the federal circuit [court] treated these claims, you know, almost derisively. They just smacked them," says Minnesota patent attorney Warren Woessner, former chair of the biotech committee of the American Intellectual Property Law Association. Woessner had predicted Ariad's defeat. “They won in a jury trial-big deal. They got some Nobel prizewinners up there to say how wonderful this was, and the jury folded like a cheap lawn chair. That's not uncommon. But the [appeals judges] just demolished this."

In Woessner's mind, Ariad was unlikely to prevail in the long run, given past decisions of the US Court of Appeals for the Federal Circuit (known simply as 'the federal circuit'). Allowing under federal circuit precedent," he notes, adding, "It just wasn't going to happen." Woessner NFкB pathway. such broad claims "was essentially impossible

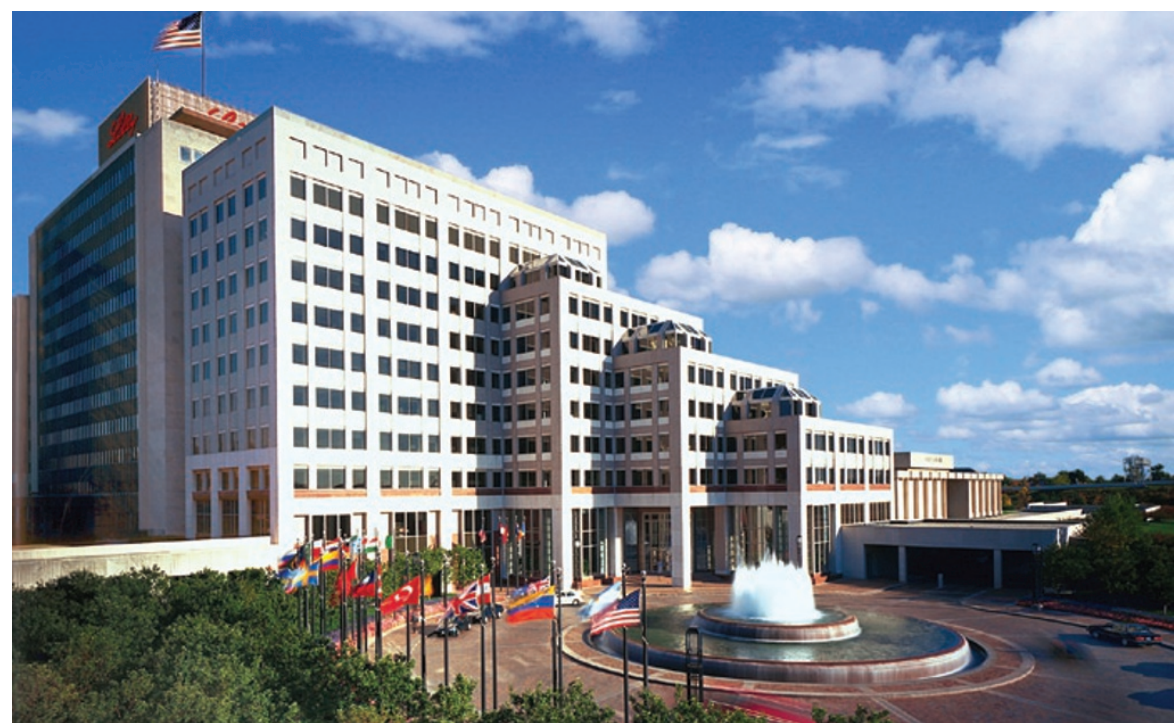

Lilly headquarters - the company has won a legal dispute with Ariad over patent rights surrounding NFkB. 